\title{
The Effect of Using K.W.L Strategy upon Acquiring Religious Concepts
}

\author{
Khalid A. Alsoudi ${ }^{1, *}$ \\ ${ }^{1}$ Department $t$ of Curricula \& Instruction, Faculty of Educational Sciences, Tafila Technical University, Tafila, \\ Jordan. \\ *Correspondence: Department $\mathrm{t}$ of Curricula \& Instruction, Faculty of Education at Sciences, Tafila Technical \\ University, 66110. P.O. Box 179, Tafila, Jordan. Tel: 962-777-383-106. E-mail: awess12@yahoo.com
}

Received: February 22, $2017 \quad$ Accepted: March 14, $2017 \quad$ Online Published: April 10, 2017

doi:10.5430/wje.v7n2p31

URL: https://doi.org/10.5430/wje.v7n2p31

\begin{abstract}
This study aimed to investigate the effect of using K.W.L in acquiring religious concepts among 8th grade students in Jordan. The study sample consisted of 139 students (4sections) the sections were chosen randomly from 8th grade students from Tafila Directorate of Education. 2 sections formed the experimental group (1 section for males and 1 section for females) they were taught using K.W.L strategy, while the control groups were consisted of 2 sections 69 students ( 1 section for males and 1 section for females); they were taught by using the ordinary teaching strategy. The result indicated that the difference in achievement was statistically significant in favor of experimental groups $(\alpha=0.05)$, and there was no statistical significant differences in achievement attributed to gender or to the interaction between gender and the teaching strategy.
\end{abstract}

Keywords: K.W.L strategy, religions concepts, Islamic education, students

\section{Introduction}

Scientific development, technology, and psychological and educational theories changed the role of a teacher from a person who taught student to memorize and the source of knowledge to a person who facilitate learning, guide students, advise them and provide them with strategies to solve problems and encourage them to be self-directed learners (Aisrah,2010), according to those teachers, they should be aware of knowledge development, practicing the best teaching methods and must be change makers in students way of thinking (Hashimi and Gazawi,2009) . Marie and Helah (2002) stated that: the increase in teacher's knowledge about teaching strategies will make learning process more enjoyable, more appropriate to students needs, and highly correlated to their abilities, their daily lives, preferences and aspirations of the future. The new teaching strategies and methods transferred the educational process from teacher centered to be students centered which enhanced student' self-directed learning (Melhem, 2006). Metacognitive strategies is one of the recent development teaching strategies, it focused upon learners themselves and considered them self regulated thinkers, self-assessors and direct their learning to achieve their goals (Schraw and Denison,1994). Know, What, and Learn (K.W.L) is one of metacognitive strategies (what do I know? what do I want? and what have I learned); this strategy activate students prior knowledge and make it a starting point for linking the new information in order to have the meaningful of learning, it increases the students self- confidence and his/her ability to plan and monitor his/her work. Hashimi and Delemi (2008) and Nofal (2007) indicated that K.W.L stimulates students thinking by reinforcing questioning, independent thinking and setting objectives which lead them to achieve their goal. While the present teaching practices concentrated upon memorizing information and limited opportunities of thinking activities and problem solving (Mazroa 2006 and Gareri, 2007). The Ministry of Education (MOE) in Jordan realized the importance of teaching strategies, according to that it organized many workshops to train teachers, encourage students to be self learners, emphasized on in-service training and held the educational development conference in Amman 2015 (MOE, 2015). The religious concepts form the core of Islam principles and considered to be the basics of the individual moral behaviors. these concepts must be related to the students' daily life and their needs (Jalad, 2004). The traditional methods in teaching religious concepts have many shortcomings and they are inappropriate for the new challenges in learning strategies and the development in information and technology. Dorothy (1989) indicated that teaching method should take into consideration the students psychological, educational, and social needs. Basic stage of education considered to be critical stage in 
students' life, because it forms the base for the next stages in education, so it needs special consideration in transferring knowledge to the students, taking into account the emotional, cognitive and sensory-motor objectives that the students should mastere. (Amer, Eid and Mustafa, 2013). The researcher noticed from his experience as a teacher, supervisor and faculty member that Islamic education teachers used teaching strategies in which the teacher plays the main role in teaching process; they ignore the students' role in learning and the absence of thinking development, this also approved by the study of Mustafa and Almohamad (2016). According to that the researcher conducted this study to investigate the effect of K.W.L in acquiring religious concepts in teaching Islamic Education.

Metacognition is a concept that first established by John Flavell in 1979 to refer to the effective and meaningful learning, different teaching strategies were emerged that based upon metacognition: one of these is K.W.L which established by Ogle Dona in USA, this strategy utilizes previous student knowledge to acquire the new knowledge and makes the meaningful for knowledge and learning (Abu Jade and Nofal, 2010). This strategy consists of 3 stages: what I know? What I want to know? and what I learned? The objective of K.W.L as determined by Ogle is to involve students in active reading process by asking questions and thinking about the concepts that they found through reading. This strategy depends upon reading which involved in understanding, and prior knowledge which forms the core of reading comprehension (Abdalbari, 2010) In order to implement K.W.L in classroom the teacher should follow the following steps:

1- Clarifying the topic: by writing the lesson title on the board.

2- Determination of the previous knowledge needed for the new knowledge $(\mathrm{K})$.

3- What I want to know (W); the teacher should determine the instructional objectives of the lesson.

4-Reading comprehension: The students have to read and understand the new topic.

5- Post reading: students start reflecting about what they understand, and ask questions about what they need to know (L).

6- Evaluation: students start to evaluate what they knew and understood. (Atieh, 2009 and Hashemi and Delemi, 2008).

During the teaching process, the teacher role is to: motivate students, encourage student to determine what they need to know, identify the previous knowledge needed for the new knowledge, encourage students to cooperate with others and to be self-learners, encourage and lead classroom discussion, and direct the students to achieve the instructional objectives. (Atieh, 2009). While, the role of the student in K.W.L.is to: Determine his previous knowledge, think about of the new topic issues, ask questions, classify the ideas about the new knowledge, cooperate with others, lead group discussion, correct mistakes about information he acquired (khafuji, 2011).

Many studies were conducted about K.W.L; the study of Abuajwa (2009) aimed to investigate the effect of K.W.L in developing problem solving skill in chemistry, the sample of the study consisted of (31) students for the control group from Arafat secondary school for gifted students in Palestine. The researcher developed a list of chemical problem skills to collect the data. The results indicated statistical significant differences $(\alpha=0.05)$ between the 2 groups in favor of experimental group.

The study of Abdullah (2010) aimed to investigate the effect of K.W.L teaching strategy upon achievement in geometry and geometrical thinking among 8th grade students. The study sample consisted of 80 students from Egypt, they were divided into experimental group and control group, the experimental group was taught geometry by using K.W.L strategy, while, the control group was taught by using the traditional method of teaching. The result showed statistical significant difference in achievement test and in geometrical thinking test in favor of experimental group. Zahrani (2011) investigated the effect of K.W.L upon achievement in English language among 7th grade students in Mecca, the study sample consisted of (62) students; they were divided into 2 groups: experimental group and control group, K.W.L used in teaching the experimental group, while, the control group was taught by using traditional method of teaching. The results showed a significant difference in means in favor of experimental group. Abusultan (2012) studied the effect of K.W.L on developing mathematical thinking and concepts among 9th grade female students in sheik Ajleen school in Gaza (76 students), she divided them into experimental and control group, she found that the differences in means were statistically significant $(\alpha=0.05)$ in favor of the experimental group. Aram (2012) used experimental design to investigate the effect of K.W.L upon acquiring scientific concepts and critical thinking among 7th grade students in khan younes. The results indicated statically significant differences in means in favor of the experimental group which taught using K.W.L strategy. Afifi (2013) study aimed to know the effect of implementation K.W.L in modifying the technological concepts among 9th grade students, the researcher used the experimental design: 35 girl students were taught using K.W.L strategy. The results indicated significant differences 
in means of modifying teaching technological concepts in favor of experimental group. The study of Abualosh (2015) used K.W.L to show the effect of this strategy upon acquiring scientific concepts and attitudes among 8th grade students. The study sample consisted of (31) students for the experimental group and (29) students for the control group. The results showed statistically significant differences in acquiring scientific concepts and scientific attitudes in favor of experimental group.

Finally, Mustafa and Muhammad (2016) conducted a study aimed to know the effect of K.W.L upon achievement in Islamic Education in Mecca at Saudi Arabia, the researcher used quasi- experimental design by using 2 groups (experimental and control groups), the results showed that the experimental group who taught using K.W.L had higher achievement than the control group.

\section{Purpose of the Study}

This study aimed to investigate the effect of KWL upon acquiring religious concepts.

\section{Problem Statement}

Islamic education is one of the subjects that encountered many problems in teaching process. Teachers play the main role in the education process; which concentrates on memorization; resulting in the lack of response and participation from the students and they feel bored (Jamal, 2005 and Abualosh, 2006); on the other side, many studies found that the effective teaching depends upon involvement of students in the education process and effectives of K.W.L in learning and students' achievement (Ghamdi,2015 Abualosh 2015, Aram, 2012 and Barakat, 2008). According to that the researcher conducted this study to investigate the effect of K.W.L in acquiring religious concepts among $8^{\text {th }}$ grade students.

\section{Study Questions}

This study is attempted to answer the following questions:

1- What is the effect of K.W.L in acquiring religious concepts of Islamic Education Subject among $8^{\text {th }}$ grade students?

2- Is there statistically significant difference in acquiring religious concepts attributed to students' gender?

3-Is there statistically significant difference in acquiring religious concepts attributed to the interaction between gender and teaching strategy?

\section{Study Objectives}

This study constructed to achieve the following objectives:

1- Constructing instructional program based upon K.W.L strategy to acquire religious concepts in Islamic Education among 8th grade students.

2- Investigating the effectiveness of K.W.L instructional program in acquiring religious concepts in Islamic education among 8th grade students.

3- Investigating the effect of gender and teaching strategy and the interaction between them upon acquiring religious concepts in Islamic Education.

\section{Study Importance}

This study has the following practical and theoretical importance:

1- Providing new teaching approach based on K.W.L

2- Providing Islamic education supervisors with a new teaching strategy to train teachers.

\section{Procedural Definitions}

- K.W.L strategy: One of the metacognitive strategies which consists of three words:

Know, Want and Learn.

- Religious concepts: the mental image that the students form about Islamic system, Islamic morals and Islamic 
principles which will be measured by achievement test designed for this study purposes.

\section{Study limitation}

The study was conducted under the following limitation

1- The study was conducted using 2 units of Islamic education text book for 8th grade students in Jordan.

2- The sample of the study consisted of $28^{\text {th }}$ grade students from 2 schools at Tafila Directorate of Education; one represents male students while the other represents female students.

This study accomplished during the $2^{\text {nd }}$ semester 2016.

\section{Methodology}

\subsection{Design}

The researcher adopted the quasi experimental design to assess the effect of K.W.L upon acquiring religious concepts among $8^{\text {th }}$ grade students in Jordan; this design depends upon using 2 groups: experimental group which was taught by using K.W.L and the control group which was taught by using the traditional method of teaching.

EG: O1 x O1

CG: $\mathrm{O} 1-\mathrm{O} 1$

EG: Experimental Group

CG: Control Group

$\mathrm{x}: \mathrm{K} . \mathrm{W} . \mathrm{L}$

- : Traditional method of teaching

O1: Pre test.

\subsection{Participants}

The study was applied on 139 students from $8^{\text {th }}$ grade in 2 schools (Abu Baker school for males and Mariam school for females from Tafila Directorate of Education) during the second semester 2016, the experimental group consisted of 70 students ( 31 male and 39 female), this group was subjected to K.W.L strategy. The control group consisted of 69 students ( 26 male and 43 female) this group was taught by using the traditional method of teaching. Table 1 represents the participants' distribution:

Table 1. The Participants

\begin{tabular}{lccc}
\hline & Female & Male & Total \\
\hline Group & 43 & 26 & 69 \\
Experimental & 39 & 31 & 70 \\
Total & 82 & 57 & 139 \\
\hline
\end{tabular}

\subsection{Procedure}

In order to make sure that the 2 groups were equivalent pretest for religious concepts was applied on the 2 groups. Table 2 represents means and standard deviations for religious concepts of the 2 groups.

Table 2 shows differences in means between the 2 groups and 2 gender; so, in order to indicate if these differences were statistically significant 2-way ANOVA was used, table 3 represents the findings: 
Table 2. Means and Standard Deviations for the Pretest of Acquiring Religious Concepts for Experimental and Control Groups

\begin{tabular}{ccccc}
\hline Group & Gender & No & Mean & Standard Deviation \\
\hline control & $\mathrm{M}$ & 26 & 55.00 & 17.16 \\
& $\mathrm{~F}$ & 43 & 54.58 & 29.87 \\
& $\mathrm{~T}$ & 69 & 54.74 & 25.68 \\
Experimental & $\mathrm{M}$ & 31 & 55.10 & 23.58 \\
& $\mathrm{~F}$ & 39 & 54.72 & 25.30 \\
Total & $\mathrm{T}$ & 70 & 54.89 & 24.38 \\
& $\mathrm{M}$ & 57 & 55.05 & 20.72 \\
& $\mathrm{~F}$ & 82 & 54.65 & 27.62 \\
& $\mathrm{~T}$ & 139 & 54.81 & 24.94 \\
\hline
\end{tabular}

Table 3. 2-Way ANOVA for Pretest

\begin{tabular}{lccccc}
\hline source & Sum of squares & d.f & mean squares & F & sig \\
\hline Teaching strategy & 0.50 & 1 & 0.50 & 0.001 & 0.98 \\
gender & 5.31 & 1 & 5.31 & 0.008 & 0.93 \\
Strategy* gender & 0.013 & 1 & 0.013 & 0.000 & 0.996 \\
error & 85841.10 & 135 & 635.86 & - & - \\
total & 85847.14 & 138 & 622.10 & - & - \\
\hline
\end{tabular}

Table (3) indicated that the differences in means between experimental group and control group were not statistically significant $(\alpha=0.05)$.

\subsection{Test Validity}

The validity of the test was checked using judgment validity, the test was checked by 12 experts in curriculum and Islamic education teaching methods, and according to their judgment the items were modified.

\subsection{Test Reliability}

To check the test reliability a pilot sample consisted of 208 th grade male students and 20 female students were chosen to find internal consistency by using KR20. The reliability coefficient $=0.918$.

\subsection{Manual of K.W.L}

The researcher developed a manual to implement K.W.L in teaching Islamic education according to the following steps:

- Content analysis for the 2 units of Islamic education.

- Reconstructing the 2 units using K.W.L strategy. (Making benefit from related literature (Atieh $(2008,2009)$ and Mustafa and Muhammad 2016).

- Checking the validity of the manual by using expert judgment.

\subsection{Variables}

Independent variable:

Teaching strategy "K.W.L" and traditional method of teaching.

Gender: male and female.

Dependent variable: acquiring religious concepts.

\subsection{Statistical Analysis}

In order to answer the study questions SPSS was used to calculate means, standard deviations and 2- way ANOVA. 


\section{Results and Discussion}

\subsection{Question 1}

To answer question 1 which states: what is the effect of K.W.L in acquiring religious concepts of Islamic Education Subject among 8th grade students? Means and standard deviations were used as table 4 represents the findings.

Table 4. Means and Standard Deviations for the Pretest of Acquiring Religious Concepts for Experimental and Control Groups

\begin{tabular}{ccccc}
\hline Group & Gender & No & Mean & Standard Deviation \\
\hline control & $\mathrm{M}$ & 26 & 65.81 & 18.84 \\
& $\mathrm{~F}$ & 43 & 60.16 & 28.27 \\
& $\mathrm{~T}$ & 69 & 62.29 & 25.49 \\
Experimental & $\mathrm{M}$ & 31 & 82.00 & 26.55 \\
& $\mathrm{~F}$ & 39 & 85.41 & 27.84 \\
& $\mathrm{~T}$ & 70 & 83.90 & 27.13 \\
Total & $\mathrm{M}$ & 57 & 74.61 & 24.54 \\
& $\mathrm{~F}$ & 82 & 72.17 & 30.89 \\
& $\mathrm{~T}$ & 139 & 73.17 & 28.39 \\
\hline
\end{tabular}

Table 4 showed that the means for experimental group are higher than control group. In order to examine if the difference in means is statistically significant $(\alpha=0.05)$, 2-way ANOVA was used as table 5 represents the findings.

Table 5. 2-Way ANOVA for Pretest for Post Test for Acquiring Religious Concepts

\begin{tabular}{lccccc}
\hline source & Sum of squares & d.f & mean squares & F & sig \\
\hline Teaching strategy & 16058.30 & 1 & 16058.30 & 23.000 & 0.000 \\
Gender & 31.68 & 1 & 31.68 & 0.45 & 0.832 \\
Strategy* gender & 685.49 & 1 & 685.49 & 0.982 & 0.324 \\
Error & 94257.34 & 135 & 698.20 & - & - \\
Total & 111201.86 & 138 & 805.81 & - & - \\
\hline
\end{tabular}

As indicated in table 5 the differences in means in post test in acquiring religious concepts is statistically significant $(\alpha=0.05)$, this result is similar to the findings of Abuajwa (2009), Abdullah (2010) Zahrani (2011) Abusultan (2012) and Afifi (2013) the result indicates the K.W.L is an efficient strategy in learning process; because it motivates students, encourage them to be self-learners and they realize the importance of what they study and why they study.

\subsection{Question 2}

To answer question 2 which states are there statistically significant differences in acquiring religious concepts attributed to students' gender?

To answer this question means and standard deviations for male and female students were calculated, the mean for the females $=85.41$, while the males mean $=82.00$ significance

The differences in means were not statistically significant (Table 5). This could be explained by the fact that parents usually encourage their sons to be highly achievers regardless their sex and usually male and female teachers have the same qualifications and training.

\subsection{Question 3}

To answer question 3 which states are there statistically significant differences in acquiring religious concepts attributed to the interaction between gender and teaching strategy? 
To answer this question means and standard deviations and 2-way ANONA were used tables 4 and 5 represent the findings, it is found that the difference in means was not statistically significant, which means that both males and females can apply K.W.L easily and involve it in their learning and acquiring religious concepts.

\section{Conclusion}

The study concluded that K.W.L is more efficient in acquiring religious concepts compared with the traditional strategy of teaching.

\section{Recommendation}

The study recommends the following:

- Islamic education teachers should adopt K.W.L in teaching.

- Supervisors should train teachers to implement K.W.L.

- Curriculum designers should include K.W.L in curricula.

- Future studies about the relationship between K.W.L and problem solving or thinking strategies may add scientific knowledge to the education process.

\section{References}

Abdalbari, M. (2010). Reading comprehension strategies: their theories and practical implementation. Amman: Dar Almasira.

Abdullah, M. (2010). The effect of using metacognitive strategies in teaching geometry upon students, achievement and geometrical thinking among 8th grade students. Master Thesis Suhaj University. Egypt.

Abuajwa, H. (2009). The effect of self questioning in developing problems solving abilities in chemistry among $11^{\text {th }}$ grade students. Master Thesis. Islamic University, Gaza.

Abualosh, Y. (2015) The effect of K.W.L in acquiring scientific concepts and attitudes among $8^{\text {th }}$ grade students in Jordan. Master Thesis, Alabiet University. Jordan.

Abujade, S., \& Nofal, M. (2010). Teaching Thinking. Amman: Dar Almasira.

Abusultan, K. (2012). The effect of using K.W.L upon concept developing and critical thinking in math among $9^{\text {th }}$ grade students. Master thesis. Islamic University, Gaza.

Afifi, A. (2013). The effect K.W.L in modeling technological images among $9^{\text {th }}$ grade students. Azhar University: Gza.

Aisrah, W. (2010). Islamic Education teaching strategies. Amman: Dar Almasira.

Amer, A., Eid, Y., \& Mustafa, M. (2013). Islamic Education teaching strategies. Amman: Dar Zamzam.

Aram, M. (2012). The effect of using K.W.L in acquiring concepts and critical thinking among $7^{\text {th }}$ grade students, master thesis. Islamic University. Gaza.

Atieh I., \& Saleh, M. (2008). The effect of K.W.L and thinking, make pairs and share in teaching math upon communication, math creativity among elementary grades students. Journal of Education. College Banha University. 18(76). 50-85.

Atieh, M. (2009). Metacognitive strategies in understanding reading. Amman: Dar Almasira.

Barakat, N. (2008). The effect using multiple intelligences, six hats, and K.W.L in teaching upon achievement and math abilities among $9^{\text {th }}$ grade female students in Mecca. PhD Dissertation, um Al- Qura University.

Dorothy and others, Grand and Others. (1989). Today elementary social studies. Herbert row: London.

Flavell. J. (1987). Speculations about the Nature and development of metacognition. In Weinert. F. \& Kluwe, R. Metacognition Motivation and Understanding, Hillsdale, Ni: Lawrence Erlbaum.

GarEri, S. (2007). Teaching thinking. Bagdad: Musta publications.

Ghamedi, I. (2015). The effect of K.W.L-plus in developing creative thinking and information processing in math among $9^{\text {th }}$ grade students. Studies in Curricula and Methods of Teaching, 210, 15-76. 
Halaq, H. (2006). Methods and curricula of teaching science. Biruit: Dar Alnahd.

Hashimi, A., \& Delemi,T (2008). Modern strategies in the art of teaching. Amman: Dar Alshorok.

Hashimi, A., \& Gazawi, F. (2009). Knowledge economy and teacher components. Dubai: Dar Alketab Aljamie.

Jalad, M. (2004). Teaching Islamic Education. Amman: Dar Almasira

Jamal, A. (2005). Teaching history in 21 century Cairo. World Books Publications.

Khafaji, G. (2011). The effect of using K.W.L upon reading comprehension. Master Thesis. Um Al-Qura University.

Marie, T., \& Hielah, M. (2009). Modern educational curricula. Amman: Dar Almasira. Master Thesis Azaher University.

Mazroa, H. (2006). The effect of circular house strategy in developing metacognitive abilities and achievement among secondary school female students. Arabian Gulf Message, 96, 23-57.

Mellhem, S. (2006). Psychology of learning and teaching. Amman. Dar Almasira.

MOE (Ministry of Education). (2015). Recommendations of the educational conference. Retrieved from www.moe.gov.jo.21/12/2016

Mustafa, F., \& Muhammad, F. (2016). The effect K.W.L. on achievement among $9^{\text {th }}$ grade students reading and knowledge. Journal Einshams University, 178, 57-166.

Nofal, M. (2007). Multiple intelligences in class room. Amman: Dar Almasira.

Otaibi, F. (2015). The Efficiency of using K.W.L in teaching Prophet Mohammad history upon developing moral values among elementary grades students. Master Thesis Altaef University.

Schraw, G., \& Dennison, R.S. (1994). Assessing Metacognitive Awareness. Contemporary Educational Psychology, 19, 460-475. https://doi.org/10.1006/ceps.1994.1033

Zahrani, G. (2011). The effect using K.W.L on achievement in English among $7^{\text {th }}$ grade students in Mecca. Master Thesis. Um Al-Qura University. 